\title{
Study on MOOC's Influence on Higher Education in China and its Countermeasures
}

\author{
Yuci Wang \\ Beijing University of Agriculture \\ Beijing 102206
}

\begin{abstract}
The paper explores the countermeasures of China's higher education to MOOC through the analysis of MOOC's influence on the teaching mode, teachers, students, education teaching management, education ecology of China's universities: renew education idea, strengthen the construction of teaching staff; help students master online learning methods and improve their own learning ability; introduce MOOC into classroom teaching to develop a blended teaching mode in an innovative way; innovate education teaching management system and establish the standard of MOOC development; include MOOC into the development planning of universities and promote the localization of MOOC.
\end{abstract}

Keywords-MOOC; higher education; influence; countermeasures

\section{INTRODUCTION}

MOOC is the acronym for "Massive Open Online Course". It is a teaching activity that is based on computer technology and Internet application, and puts the necessary resources of teaching activities online through network platform, such as teaching video, syllabus, courseware, reference materials, tests and homework, so that learners can gain knowledge and skills through online learning and interaction. As a new education form, MOOC has attracted wide attention since it appears. From the appearance of the first MOOC course in 2008, to the establishment of three MOOC platforms Udacity, Coursera and edX in US in 2012, more than 200 universities around the world have joined the platform. The development of MOOC has entered the blowout state. In 2014, "China University MOOC" was officially launched. China's higher education enters the MOOC era.

\section{The Influence OF MOOC ON CHINA'S HigheR EDUCATION}

\section{A. The influence of MOOC on the teaching mode of universities.}

Current teaching model reflects the characteristics of the industrial revolution. To improve the efficiency of the standardized teaching, let students receive education on the production line, namely the teacher talking on stage and the students listening below. Teachers face dozens of students, and teach them the existing knowledge face to face by blackboard and multimedia. The whole teaching process focuses on the teacher, and the students are passively listening to the teacher' lecture. Therefore students' learning initiative and independence has been ignored. It is not conducive to the cultivation of students' innovation ability. In this traditional teaching mode, all students receive the same education. Its disadvantage is that the students' knowledge, ability and level are different; some students learn faster, some students learn more slowly. Some students may still can't master the concept after the teacher explains it for several times. On the contrary, when the teacher explains a concept for many times in class, some students will feel bored. The appearance of MOOC has brought impact to the traditional teaching mode. In the learning process of MOOC, the Internet is used as a platform and the whole process of teaching is videoed. The online teaching allows students to get rid of the restriction of age and time, and start from their own needs and interests to listen to the lecture of teacher, conduct online discussion and finish the homework. The problems can be replayed repeatedly. Teachers can effectively know the students' learning situation. MOOC provides students with more flexible learning content, the teaching process pays more attention to the interaction between teachers and students and problems solving. Students' ability of analyzing and resolving problems is improved in discussion and communication. [1] MOOC pays more attention to students' learning gain, forming a new type of teacher-student relationship centered on students and guided by teachers. MOOC has brought a shock to the traditional teaching mode, but it does not mean that MOOC can replace classroom teaching. MOOC also has many shortcomings, and can only be treated as the supplement of classroom teaching. Traditional classroom teaching has unique advantages in humanistic quality, team consciousness, cooperation ability, critical thinking ability compared to MOOC. In addition, MOOC cannot bring students the influence of campus culture.

\section{B. The influence of MOOC on teachers in universities.}

Under the teaching mode of MOOC, teachers spend more class time on online discussion. They need to answer students' questions. Therefore, there are higher requirements for teachers' knowledge breadth and depth. It also requires teachers to fully understand the psychological characteristics of students, so that they can predict students' questions before class, and pay attention to discussion ways and methods. This has put forward higher requirements for the comprehensive quality of teachers. Teachers interact with students through the video and email in a timely manner, and understand the students' interests through the click rate of courses on MOOC platform. In this way, teacher can have more clear understanding of students' learning effect, and adjust the key and difficult points of 
teaching according to the dynamic data in time. MOOC can't take the place of classroom teachers, nor can it reduce teachers' teaching task. MOOC provides teachers with free teaching space, and it has put forward higher requirements for teachers to well manage the teaching space. MOOC gives the right of course selection to students, and the quality of teachers' teaching quality determines the number of students who choose the course. And the number of students who choose the course determines whether to open the course or not. In the face of such pressure, teachers need to change the teaching attitude and methods, improve teaching level, so as to improve the quality of personnel training. Teachers should recognize that their "authority" has been challenged. MOOC opened by famous teacher may be more attractive to students. Teachers should change their roles step by step from knowledge imparter to learning supervisor and instructor, help students improve their ability of self-learning and ability to analyze and solve problems, and cultivate students' innovation consciousness and ability. [2]

\section{The influence of MOOC on university students.}

After the MOOC resources are released on the Internet, students can select courses according to their interests and time and learn freely. The rich course resources and short course time makes it easy to arouse students' learning enthusiasm and initiative. On the university alliance MOOC platform established by universities in China, MOOC resources are gradually introduced into elective courses and general courses, turning students' learning attitude of "ask them to learn" into 'they want to learn". The role of education is reflected in that teachers' teaching is for the better learning of students. MOOC actually restore the nature of study. It embodies the interaction between teachers and students and the communication between students. It attaches importance to students' learning experience. Students' understanding of knowledge is gradually deepened in the process of interaction and communication. On the other hand, MOOC are based on Internet platforms. Without face-toface communication between teachers and students, there comes more human-computer dialogue, lack of supervision and restraint mechanisms. Therefore, students' learning interest cannot be stimulated by teachers, and the persistence of learning is not easy to solve. However, on the Internet, it is difficult to guarantee that it is the learners themselves that are learning, and whether the homework is plagiarized, and the authenticity of academic level cannot be verified. Therefore, MOOC makes higher demands on students' autonomy and selfdiscipline.

\section{The influence of MOOC on the teaching management of education in universities.}

The appearance of MOOC has caused great changes of higher education in the teaching philosophy and teaching mode, which has brought new problems to the educational teaching management in universities. How to realize the reasonable connection between online education and classroom teaching is a new challenge for educational teaching management in universities. To the teaching administrator of universities, MOOC is a new thing. And there will be new problems and contradictions in the construction and promotion of MOOC. The healthy development of MOOC requires corresponding teaching management system. For example, how to develop the approval standards of MOOC courses, how to share the highquality resources of MOOC, how to evaluate the teaching quality of MOOC, how to calculate the credits of MOOC, how do mobilize students' learning enthusiasm, how to stop student from cheating, how to calculate the teaching work of MOOC, how to guide teachers to actively participate in the construction of MOOC, how to reform the teaching management mode under the background of MOOC, how to build the localization MOOC course, etc. These have all posed challenges to the traditional teaching management system. The construction of excellent course and network course is quite successful and well established in some universities. How to realize the effective combination of MOOC and the existing network course resources, and avoid redundant construction and waste of resources, is also the problem that the teaching management are faced with. [3]

\section{E. The influence of MOOC on the ecology of education in universities.}

The large-scale appearance of MOOC has affected the existing higher education ecology. The free and unrestricted course choosing of MOOC allows anyone to study online and communicate with famous teachers in any place. The higher education ecology is transformed to open, and higher education is no longer the right of the minority. The popularization of higher education has coming. Therefore, MOOC provides the learners with equal opportunities on education, promoting the fairness of education and realizing the true democracy of higher education. With the development of MOOC, more and more universities have joined the MOOC platform and recognize the credits and certificates obtained by MOOC. The certification education in universities has been impacted. The appearance of MOOC also has an impact on the competition mode of universities, which are facing unprecedented competition and pressure. Under the mode of MOOC, the courses are completely free for learners' to learn. If they want to get credits or certificates, they only need to pay a small fee. By contrast, students need to pay high tuition and living expenses in ordinary universities; the learning cost is greatly increased. In addition, MOOC breaks the barrier between universities, and the national boundary restriction of competition among universities. Universities tend to face the global competition. In the construction process of MOOC platform, the key universities have obvious advantages. They can expand the social influence and popularity through MOOC, while the local universities are clearly at a disadvantage due to the limitation on experience and technology. [4]

\section{The CountermeAsures OF CHINA'S HIGHER EDUCATION TO MOOC}

\section{A. Update education concept and strengthen the construction of teaching staff.}

The development of MOOC has brought challenges to teachers in universities, and has also brought unique development opportunities. Universities should strengthen the construction of teachers, update education concept, and improve teachers' educational informationization ability. 
Teachers should realize that the informationization and modernization of education is an irresistible trend. To adapt to this change and development, we should actively participate in the construction and teaching reform of MOOC. Universities can take great achievements in the education informatization and construction of MOOC as an important basis in the title evaluation and job appointment, guiding teachers to devote more energy to teaching. Universities should focus on teacher development, train teachers, and invite relevant experts and technicians to carry out special training on the construction and use of MOOC. Encourage teachers to go out, study the excellent MOOC courses at home and abroad, learn more about MOOC, and complete a MOOC course personally. The construction of MOOC needs a good teaching team, and the university should attach importance to the construction of teaching team, so that teachers can cooperate according to their specialty, and transform the individual labor of teachers to team cooperation. Teachers should adjust their roles and functions. Under MOOC mode, students become the focus of classroom and teaching activities. Teachers are no longer just the imparter of knowledge, but the guider, partner and facilitator of learning, forming a new type of relationship between teachers and students. The functions and roles of teachers should be developed towards diversification and specialization. Teachers structure should adjust with the change of class structure. Teachers' individual character needs to transform towards the "trinity" professional team role. The lecture makes and designs the course video of MOOC, secondary teachers are responsible to arrange classroom teaching activity and answer students' questions, assistant teachers are responsible for collecting and arranging data and online tutoring. The new type of teacher team share out the work and cooperate with one another. In this way, teachers will not be distracted by the heavy workload, and it also improves the degree of specialization of MOOC teaching link.

\section{B. Help students master online learning methods and improve their self-learning ability.}

The study of MOOC requires that students not only have certain basic English skills and skilled computer skills, but also requires certain methods. Teachers should help students master online learning methods to improve students' learning effect. [5] The MOOC learning mode is the same as traditional teaching in knowledge teaching. Since it is lack of supervision online, some students who have poor self-learning ability will have burnout and not be able to finish their studies on time. Some students even cheat when they finish their homework or exams, which are all beyond the control of MOOC. Therefore, MOOC needs to have tutors to help students determine their learning objectives, stimulate students' learning enthusiasm, guide them to select course and study purposefully. The tutor should understand and supervise students' learning situation in a timely manner, and give credit authentication after the study in accordance with the relevant regulations. Improve the enrollment management, assessment management and elective course management of students' MOOC learning. Improve the network infrastructure of the school, and try best to provide free wireless network in the laboratory, study room, library, hall and other places, so as to provide good hardware support for students' MOOC learning.

\section{Introduce MOOC into classroom teaching and innovate the blended teaching mode.}

MOOC has much effect on the traditional classroom teaching mode, but it also has its limitations. It can not replace the classroom teaching. The blended teaching mode has become the exploration direction of universities to combine online education and offline education. Blended teaching mode is to combine the advantage of traditional classroom teaching and the advantage of MOOC's online education. In this way, it not only plays teachers' leading role on enlightenment, guidance and supervision of the teaching process, but also can reflect students' initiative, enthusiasm and creativity as learning subject. In blended teaching model, students can arrange the learning progress and determine the focus of the study and the content according to their own need. They can seek help from teachers or other learners online when having questions, and also can ask for teacher's help in classroom teaching. Teachers can also be liberated from repetitive lectures and have more time to communicate with students and answer questions. And students change from passive acceptance to active learning. The teaching mode changes from imparting learning to inquiry learning.

As a mainstream form of blended teaching mode, 'flipped classroom" has received more and more support. Flipped classroom transforms the traditional teaching mode of 'teachers teaching in classroom and students doing homework after class" into the mode of "students self-learning before class, teachers answering questions in class". The specific teaching process is that, before class, students learn by watching video independently, look for materials to complete the exercise, and find out problems; in class, students ask questions, and teachers organize communications and discussions to solve problems. Flipped classroom allows students to study independently. In this way students gain the initiative, arrange learning progress according to their own situation, and realize personalized learning. Flipped classroom increases communication between teachers and students. In flipped classroom, the teacher no longer represents the authority of knowledge, but rather learning guiders and partners. It narrows the distance between teachers and students, helps to build positive interactive learning atmosphere. Flipped classroom focuses on every student who needs help to make students of different abilities better, making real differential teaching possible. Students can pause the video at any time until they acquire it, no need to worry about not being able to keep pace with the teaching progress any more.

\section{Innovate the education teaching management system and establish the normative standards for MOOC development.}

The university should organize experts to reform and innovate the education teaching management system under the MOOC mode, and establish and perfect education teaching management system suitable for the development of MOOC. We should set course standards, credit certification standards, course operation standards, workload calculation standards, and teaching quality evaluation standards for MOOC courses, so that the MOOC can be established in a proper way. Regarding MOOC construction, we should attach importance to both scale and quality, develop strict course certification 
standards. MOOC courses which couldn't reach the standards are not allowed to go online. For online MOOC courses, we should organize experts to evaluate regularly, take MOOC courses with low teaching evaluation offline. Set up the corresponding reward and punishment policy, and establish incentive system. Give material and spiritual rewards to teachers and students who have excellent performance in MOOC construction, which on one hand can guide teachers to actively participate in the construction of MOOC and reform of education teaching, and on the other hand can arouse the learning enthusiasm of students, guide students to adapt to the learning mode of MOOC courses. Set the evaluation standard for the students' learning effect, and establish the system of credit reward and punishment for the students' learning attitude. Use the big data to analyze the students' learning process, learning content, examination result, online discussion and other content, and propose personalized guidance plan to students. Before choosing courses, arrange educational teaching management departments to conduct integrity education to the students, and ask students to sign integrity guarantee. For honest students, give praise, and for students, who violate integrity system, expel from school. In terms of credit certification and school management, universities should innovate management system. Universities can work together to share MOOC platform, and admit the credits that students gain from the MOOC platform. Students can obtain the second degree certificate of foreign school through MOOC platform.

\section{E. Integrate MOOC into the development plan of universities and promote the localization of MOOC}

In today's world, online education has become an important way to internationalize education. MOOC has become an important aspect of competition among universities in various countries. China's universities should seize the opportunity of the rapid development of information technology, attach importance to the development of online education in strategy, pay attention to the construction of MOOC and integrate it into the development plan. First of all, we should learn from the experience of foreign MOOC platform construction, combine our national conditions, and establish our own MOOC, actively promoting the localization of MOOC. Key and famous universities should shoulder their own social mission and responsibility to participate in and promote the construction of
MOOC platform, guiding the development of MOOC and education reform in universities. Other universities should make full use of education resources on MOOC platform, and vigorously promote curriculum construction and teaching reform to improve the quality of personnel training. Universities may formulate relevant policies, encourage teachers to join the construction team of MOOC, conduct the training of teachers, to promote the construction of online education platform and provide technical support to MOOC construction. Under the condition of insufficient MOOC construction ability, universities can introduce suitable high quality MOOC for school personnel training target based on the actual situation of school and specialties. In addition, universities should actively create conditions, cooperate with other universities to jointly build MOOC platform and share high-quality university education resources, establishing regional university alliance. At present, regional university alliance includes "China MOOC alliance" consisting of C9 universities, such as Shanghai Jiaotong University, and some 985 universities. The establishment of university MOOC alliance is conducive to the development of unified MOOC standards and sharing mechanism, and the narrowing of the gap of education resources between schools, which will help promote education internationalization and improve education quality.

\section{REFERENCES}

[1] Jiang Jun, Lai Tingting, Liu Jia. Innovation of MOOC on Traditional Higher Education in China [J]. Heilongjiang High Education Research, 2017 (2): 14-16.

[2] Li Minjing. Research on the Impact of MOOC on China's Higher Education [J]. Pioneering with Science \& Technology Monthly, 2017 (6): 71-72.

[3] Wang Yuci. Research on the Innovation of Teaching Management in Universities under the Background of MOOC[J]. Education Modernization, 2017, 4 (43): 192-195.

[4] Cui Weixia, Su Yong. Challenges and Countermeasures: China’s Higher Education in MOOC era [J]. China Adult Education, 2016 (7): 22-26.

[5] Du Shichun, Fu Zetian, Wang Yi. The Impact and Enlightenment of MOOC on China's Higher Education [J]. Higher Agricultural Education, 2014 (5): 41-43. 